\title{
Pelatihan Penerapan Online dan Blended Learning pada Masa Pandemi Covid-19 di Pondok Pesantren Arrahman Kabupaten Lombok Tengah
}

\author{
Dedi Sumarsono*, Taufik Suadiyatno, Muliani, \\ Moh. Arsyad Arrafii, Abdul Kadir Bagis \\ Program Studi Pendidikan Bahasa Inggris, Fakultas Budaya, Manajemen, dan Bisnis \\ Universitas Pendidikan Mandalika \\ *Corresponding Author. Email: dedisumarsono@undikma.ac.id
}

\begin{abstract}
This community service was aimed at training the teacher to be familiar with the usage of learning approach that can be applied in the time of covid-19. The training was conducted at Pondok Pesantren Arrahman attended by teachers of Madrasah Tsanawiyah, Aliyah, and SMK Darul Kamilin Bakan. To reach the goal of the program, the material and the application about the learning approach in detail for both online learning and blended learning was delivered to the participants. At the end of the program, evaluation was conducted by giving evaluation sheet to the participants to know whether or not the target of program is achieved. The response of the audience reveals that the program gave some good advantages for the participants as they have new knowledge about the learning approach applied in the time of covid-19. The participants also expected that the same program is conducted in the near future.
\end{abstract}

\begin{abstract}
Abstrak: Pelaksanaan kegiatan pengabdian kepada masyarakat ini bertujuan untuk melatih para guru untuk terbiasa dengan penggunaan pendekatan pembelajaran yang bisa diaplikasikan selama pandemi Covid-19. Kegitan program kepada masyarakat ini dilaksanakan di Pondok Pesantren Arrahman yang diikuti oleh guru Madrasah Tsanawiyah, Aliyah, and SMK Darul Kamilin Bakan. Untuk mencapai tujuan program ini, materi dan aplikasi tentang pendekatan pembelajaran secara detail baik untuk online dan blended learning telah disampikan kepada peserta. Diakhir program, evaluasi dilakukan dengen memberikan lembar evaluasi kepada peserta untuk mengetahuai apakah target kegiatan sudah tercapai atau belum. Respon dari para peserta menunjukkan bahwa kegiatan pengabian kepada masyarakat yang dilakukan telah memberikan manfaat yang baik bagi peserta karena mereka mendapatkan ilmu serta pemahaman yang baru terkait pendekatan pembelajaran selama Covid-19. Paserta juga berharap bahwa program yang sejenis agar bisa dilakukan diwaktu yang akan datang.
\end{abstract}

How to Cite: Sumarsono, D., Suadiyatno, T., Muliani, M., Arrafii, M., \& Bagis, A. (2021). Pelatihan Penerapan Online dan Blended Learning pada Masa Pandemi Covid-19 di Pondok Pesantren Arrahman Kabupaten Lombok Tengah. Jurnal Pengabdian UNDIKMA, 2(2), 182-188. doi:https://doi.org/10.33394/jpu.v2i2.4132

https://doi.org/10.33394/jpu.v2i2.4132

This is an open-access article under the CC-BY-SA License.

\section{Pendahuluan}

Virus Corona (Covid-19) dinyatakan sebagai pandemik oleh WHO karena penularannya yang cepat hampir ke seluruh dunia. Di awal maret tahun 2020, pemerintah Indonesia telah mengumumkan jika sejumlah orang telah terinfeksi Covid-19. Sehubungan dengan hal tersebut, pemerintah telah membuat banyak kebijakan untuk memutus penularan covid-19 seperti Pembatasan Sosial Besar (PSBB) dan Pemeberlakuan Pembatasan Kegiatan Msayarakat (PPKM. Penerapan protokol kesehatan yang ketat merupakan suatu keharusan bagi setiap orang untuk meminimalisir penularan Covid-19 seperti yang disarankan oleh 
WHO diantarnya menjaga kebersihan tangan, menjaga jarak, memakai masker, menjaga kebersihan lingkungan dan ventilasi udara, isolasi bagi orang yang terpapar Covid-19. Untuk menghindari penularan Covid-19 di lingkungan sekolah, pemerintah melalui kementrian terkait membuat kebijakan untuk meniadakan pembelajaran tatap muka di kelas dan menggantinya dengan pembelajaran jarak jauh. Bahkan, beberapa Negara telah menutup sekolah dan kampus untuk mengantisipasi penyebaran virus corona (Ivanov, 2020).

Keberadaan Covid-19 telah memaksa perubahan system pembelajaran dari interaksi langsung di kelas menjadi pembelajaran yang mengandalakan penggunakaan teknologi dan informasi atau yang lebih dikenal dengan istilah online learning. Pembelajaran jarak jauh atau online learning merupakan pembelajaran yang menggunakan internet dan perangkat teknologi yang lain untuk mengembangkan materi demi tujuan pendidikan, pemberian instruksi serta manajemen (Fry, 2001; Adedoyin and Soykan, 2020). Pembelajaran online merupakan pengalaman pembelajaran dalam lingkungan synchronous atau asynchronous menggunakan perangkat berbeda seperti handphone, laptop, computer) dengan menggunkan akses internet (Singh \& Thurman, 2019; Dhawan, 2020). Pembelajaran synchronous terlaksana dimana siswa bisa menghadiri perkuliahan secara langsung, interaksi secara langsung antara guru dan siswa sehingga terdapat kemungkinan untuk mendapatkan timbal balik lsecara instant. Di lain pihak, pembelajaran secara asynchronous merupakan pembelajaran yang diakukan tidak secara tersusun sehingga guru dan siswa tidak harus melakukan menghadiri perkuliahan secara langsung. Conklin \& Dikkers (2021) menyatakan bahwa dalam pelaksanaan perkuliahan secara online sangat direkomdasikan untuk menggunakan perangkat yang berbeda, memberikan respons secara langsung serta menyampaikan pesan baik menggunakan video, synchronous contact, atau dengan text. Adedoyin and Soykan (2020) berpendapat bahwa pembelajaran secara online memiliki banyak keuntungan seperti felxibel (Smedley, 2010), interaktif (Leszczynski et al., 2018; Wagner et al., 2008), belajar mandiri (Amer, 2007). Dalam pembelajaran online, penggunaan media seperti e-learning, email, zoom meeting, WhtaApps, Google meet, Google form, you tube bisa digunakan sebagai alternatif untuk kelas tatap muka dikelas (Basilaia in Dhawan, 2021). Lebih lanjut, Hidayatulloh, dkk (2021) menyatakan bahwa media pembelajaran menggunakan zoom meeting sangat membantu guru dalam melaksanakan proses pembelajaran.

Di dalam pelaksanaan pembelajaran jarak jauh dirasakan terdapat banyak kendala yang dihadapi oleh semua stake holder pendidikan karena dalam pelaksanaan pembelajaran jarak jauh ini sangat tergantung pada teknologi dan internet. Jaringan internet yang kuat merupakan salah satu syarat dalam pelaksanaan online learning (Ayebi-Arthur in Dhawan, 2021). Kendala teknis dan non teknis yang dihadapi selama pembelajaran jarak jauh (online) tentunya kan membuat proses dan tujuan pembelajaran akan menjadi tidak optimal. Sistem pembelajaran jarak jauh ini merupakan hal baru bagi para guru dan siswa sehingga tidak mudah untuk diaplikasikan.

Sehubungan dengan hal tersebut pelaksanaan pembelajaran tatap muka di kelas mejadi hal yang harus dilakukan. Selain itu, interaksi di kelas antar siswa dengan siswa dan guru dengan siswa merupakan hal yang sangat dirindukan baik oleh siswa dan juga guru. Dimasa pandemi Covid-19 ini, pembelajaran secara tatap muka diperbolehkan untuk dilakukan namun dengan jumlah dan durasi terbatas serta dengan mematuhi protokol kesehatan. Perpaduan antara pembelajaran jarak jauh dan pelaksanaan pembelajaran tatap muka di kelas atau yang lebih dikenal dengan istilah blended learning merupakan salah satu solusi yang bisa diterapkan semasa pandemic covid-19 ini. Blended learning merupakan salah 
satu pendekata pembelajaran yang paling logis untuk diterapkan dimasa covd-19 ini karena memberikan kesempatan untuk mengeintegrasikan pembelajaran online dan pembelajaran secara tradisional. Thorne (2003) menyatakan bahwa blended learning merupakan gabungan dari technologi multimedia; CD ROM video streaming; virtual classrooms; voicemail, email, dan conference calls; online text animation, and video-streaming. Pendekatan blended learning menekankan bahwa pembelajaran tidak hanya dilakukan secara tatap muka namun juga pembelajaran bisa dilakukan dilakukan di luar kelas yakni secara online (Zainuddin, and Keumala, 2018). Gunawan, dkk (2016) menyatakan bahwa penggunaan blended learning bisa memotivasi siswa untuk belajar secara flexible, mandiri dan meningkatkan kemampuan meneliti siswa. Uzur \& Senturk (2010) juga menyatakan bahwa blended learning secara optimal bisa meningkatkan kepuasan guru dan siswa.

Untuk menerapkan pendekatan pembelajaran baik jarak jauh ataupun blended learning, pemahaman mendalam mengenai kedua pendekatan tersebut oleh semua stake holder pendidikan terutama guru dan siswa mutlak harus dimiliki. Pembelajaran secara online membuat siswa tidak hanya belajar materi namun juga mereka perlu belajar bagaimana cara melakukan online (Lowes and Lin, 2015; Borup et al, 2019). Berdasarkan pengamatan terkait proses pembelajaran selama pandemic Covid-19 ini, pemberian materi pelajaran sering kali dilakukan dengan meminta siswa untuk datang kesekolah hanya untuk sekedar mengambil materi pelajaran yang akan dibahas. Jika siswa telah selesai mengerjakan tugas yang telah diberikan mereka akan kembali ke sekolah hanya untuk mengumpulkan tugas dan mengambil materi pelajaran baru. Phenomena yang lain juga yakni guru akan melakukan kunjungan kerumah siswa untuk melakukan proses belajar secara terbatas. Phenomena-pnomena ini sejatinya bisa di lakukan secara lebih mudah baik secara online ataupun blended learning jika guru dan siswa memahami konsep dan penggunaan pendekatan pembelajaran online dan blended learning.

Pelaksanaan pengabdian masyarakat ini bertujuan untuk memberikan pemahaman yang lebih comprehensif tentang konsep dan penggunaan pendekataan pembelajaran yang dilakukan secara jarak jauh (online) dan kombinasi antara pembelajaran tatap muka dan juga online atau yang lebih dikenal dengan istilah blended learning. Diharapkan dengan pelaksanan pengabadian ini, para guru dan siswa akan lebih memahami konsep dan keuntungan penggunaan online learning dan blended learning di masa pandemik Covid- 19 .

\section{Metode Pengabdian}

Metode pelaksanaan kegiatan pengabdian terdiri dari tiga tahapan, yaitu: tahap awal, tahap pelaksanaan kegiatan, dan tahap evaluasi kegiatan.

\section{1) Tahap Awal (Perencanaan)}

Pada tahap awal pelaksanaan pelatihan ini lebih banyak berupa koordinasi baik itu koordinasi antar tim maupun koordinasi antara tim dan pihak sekolah yang menjadi lokasi pelaksanna kegiatan pengabdian. Langkah-langkah yang dilakukan tim sebagai langkah awal meliput:

a) Koordinasi antar tim meliputi: pemilihan tema, penyiapan materi, dan pembagian tugas tim.

b) Koordinasi antara tim dan pihak sekolah meliputi: koordinasi dengan Kepala Madrasah Tsanawiyah, Aliyah, dan juga SMK Darul Kamilin Bakan mengenai kesiapan waktu pelaksanaan dan peserta pelatihan. 


\section{2) Tahap Pelaksanaan Kegiatan}

Tahapan pelaksanaan kegiatan ini dapat diuraikan sebagai berikut Pada tahap Pelatihan dan pendampingan, tim menjelaskan dan memberikan pemahaman yang lebih comprehnsif terkait dengan pendekatan pembelajara dan cara aplikasinya serta keuntungannya yang bisa diterapkan selama pandemic Covid-19. Kegiatan dilaksanakan di Musholla di Pondok Pesantren yang dihadiri oleh Kepala madrasah dan guru ditingkat Tsanawiyah, Aliyah, SMK Darul Kamilin Bakan yang berjumlah 22 orang.

\section{3) Tahap Evaluasi Kegiatan}

Evaluasi kegiatan dilakukan setelah kegiatan pelatihan dan pendampingan selesai dilakukan untuk mendapatkan gambaran jelas berkaitan dengan kelanjutan program ke depan. Segala bentuk permasalahan, kekurangan, dan kelebihan selama kegiatan menjadi acuan penyusunan kegiatan berikutnya. Intrumen yang digunakan untuk evaluasi adalah angket.

\section{Hasil Pengabdian dan Pembahasan}

Hasil kegiatan Pengabdian Kepada Masyarakat yang dilaksanakan selama sehari yaitu pada tanggal 25 Agustus 2021 dalam bentuk pelatihan guru di tingkat Tsanawiyah, Aliyah, dan SMK di Darul Kamilin, Desa Bakan, Kecamatan Janapria, Kabupaten Lombok Tengah, Provinsi Nusa Tenggara Barat terdiri dalam beberapa tahapan sebagai berikut.

\section{1) Tahap Persiapan}

a) Koordinasi dengan pihak sekolah

Tujuan dari kegiatan ini untuk memetakan guru di sekolah tersebut sesuai dengan jenis kelamin dan nama sekolah serta dukungan sekolah untuk memperlancar pelaksanaan kegiatan pengabdian kepada msyarakat. Hasil dari koordinasi ini adalah jadwal pelaksanaan kegiatan pengabdian, pembagian tugas antara tim pengabdian dan pihak sekolah, serta terdatanya nama-nama guru yang berkomitmen mengikuti kegiatan. Adapun jumlah peserta yang menghadiri pelakssanaan kegiatan PKM berjumlah sekitar 22 orang guru mata pelajaran yang berbeda yang terdiri dari 5 perempuan dan 17 lakilaki.

b) Penyusunan bahan pelatihan

Penyusunan bahan pelatihan dilakukan oleh tim pengabdian dengan bertujuan untuk memudahkan peserta, bahan pelatihan disertai dengan contoh. Bahan pelatihan meliputi: konsep dasar pendekatan pembelajaran, keuntungan, serta cara-cara pengaplikasian pendekatan pembelajaran baik secara online ataupun blended learning yang biasa diterapkan dimasa Covid-19.

\section{2) Tahap Pelaksanaan Kegiatan}

Pelatihan dilaksanakan di Madarsah Tsanawiyah dan Aliyah, dan juga SMK Darul Kamilin desa Bakan Lombok Tengah. Pelatihan diikuti oleh para guru dari berbagai guru mata pelajaran. Kegiatan awal dilakukan dengan penyampaian kata sambutan oleh ketua Yayasan Arrahman yang menaungi ketiga lembaga tersebut. Setelah itu dilanjutkan dengan penyampaian materi oleh tim yang dibagi dalam dua tahapan yaitu; materi pertama mengenai konsep dasar serta landasan hukum pelaksanaan pembelajaran secara jarak jauh yang dilaksanakan selama pandemic Covid-19. Penjelasan yang lebih comprehensive perihal konsep dasar, jenis, cara, dan keutungan pembelajaran secara online ataupun blended di sesi kedua. Setelah penyampaian materi selesai, kemudian dilanjutkan dengan pendalaman materi yang dilakukan dengan metode diskusi/ tanya jawab serta pemberian angket kepada peserta perihal pelaksanaan kegiatan yang bertujuan untuk mengevealusi proses kegiatan serta untuk perbaikan kegiatan selanjutnya. 



Gambar 2. Suasana Pelaksanaan PKM

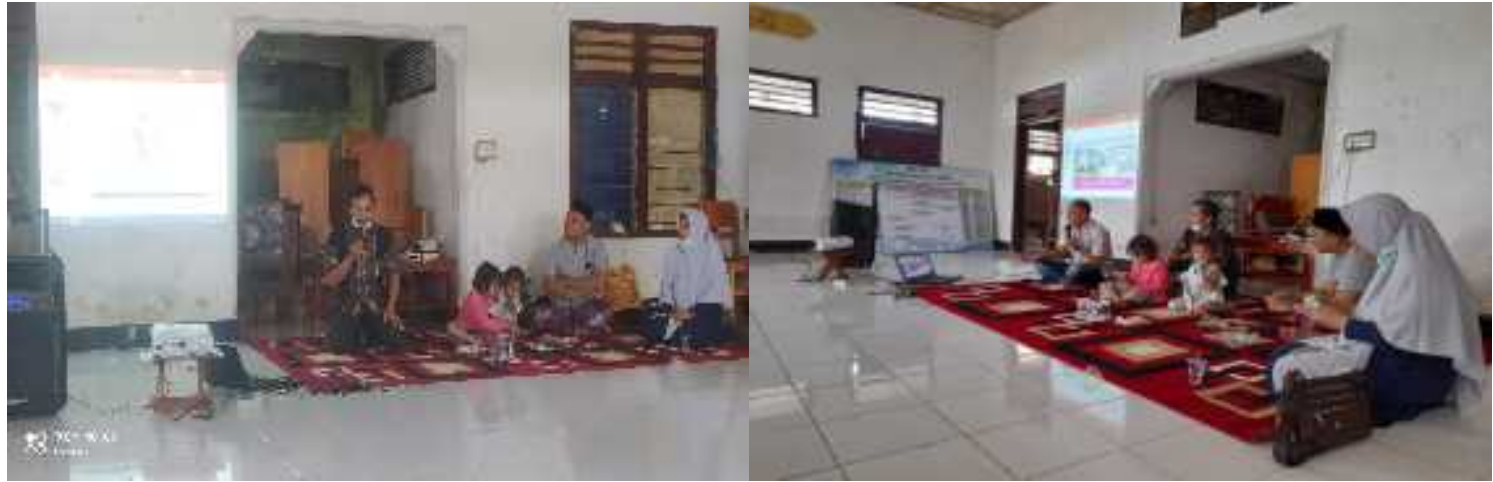

Gambar 3. Pemaparan Materi oleh Tim PKM

Kegiatan PKM yang dilakukan di Pondok pesantren Arrahman berlangsung dengan lancar. Mitra kegiatan sangat antusias dengan pelaksanaan kegitan yang telah dilakukan. Hal ini tercermin dengan kehadiran ketua yayasan Pondok Pesantren Arrahman dalam memberikan sambutan penerimaan serta mengikuti proses pelaksanaan kegiatan. Kegiatan PKM selain diikiuti oleh para guru, diikiuti juga oleh kepala Madrash Aliyah dan Tsanawiyah serta Kepala SMK Darul Kamilin. Selama pelaksanaan kegiatan, para peserta sangat antusias dalam mengikuti setiap tahapan kegiatan. Setelah pemaparan materi selesai dilakukan, Pertanyaan dilayangkan secara langsung oleh peserta terkait dengan penggunaan pendekatan serta media pembelajaran dimasa Covid-19.

Berdasarkan hasil jawaban umpan balik dari hasil angket yang telah disebarkan kepada para peserta. Hasil angket tersebut menunjukkan bahwa guru Madrasah baik Tsanawiyah, Aliyah dan SMK Darul Kamilin memahami materi pelatihan yang disampaikan karena pelatihan tersebut sangat relevean dan informative terkait dengan pendekatan belajar yang bisa digunakan selama Covid-19. Para guru rata-rata setuju jika pelatihan dilakukan 
dimasa yang akan datang karena para guru berpendapat bahwa pelatihan secara umum memenuhi tujuan pelatihan. Selain itu, para peserta merasa mendapat pengetahuan baru tentang pendekatan pembelajaran yang bisa ditrapkan selama Covid 19.

Respon lain dari hasil angket terkait dengan peningkatan kualitas pelatihan juga menunjukkan bahwa para peserta berharap perlu adanya pengembangan media pembelajaran yang bisa diaplikasikan di covid-19. Mereka juga berharap akan adanya pelatihan-pelatihan lanjutan yang terkait dengan memperbanyak waktu untuk praktik-praktik langsung terkait dengan pendekatan pembelajaran yang bisa diaplikasikan selama covid-19.

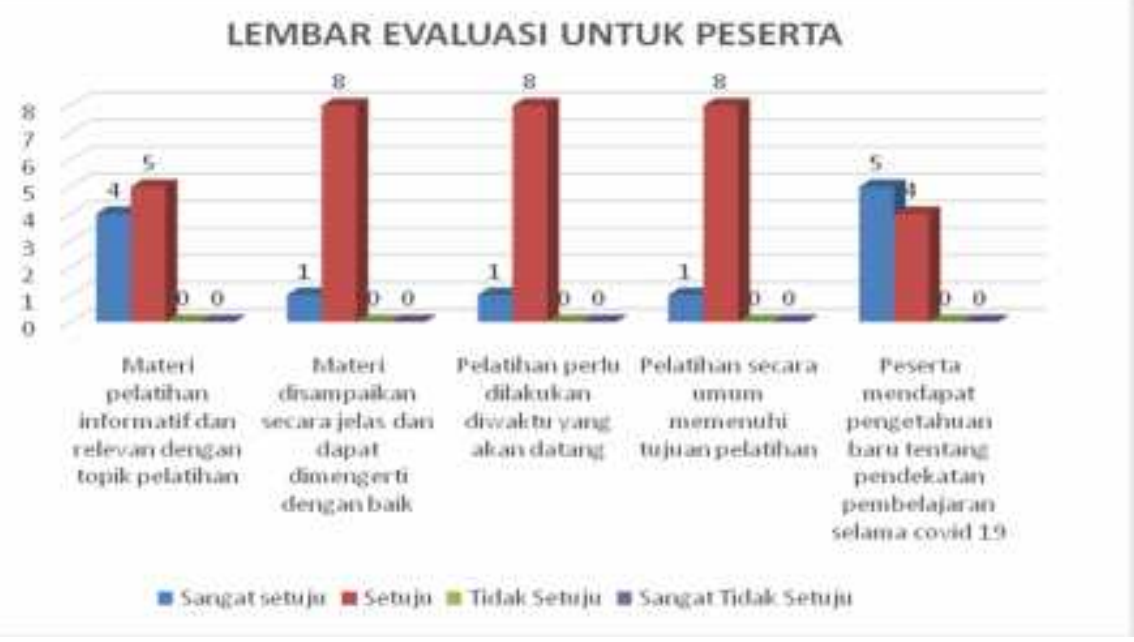

Gambar 4. Bagan Lembar Evaluasi untuk Peserta

Luaran kegiatan pengabdian yang dilakukan di Tsanawiyah dan Aliyah serta SMK Darul Kamilin Bakan yang berada dibawah naungan yayasan Arrahman mencapai target yang direncanakan yaitu:

1) Pelatihan diikuti oleh para guru dari berbagai guru mata pelajaran di Tsanawiyah dan Aliyah serta SMK Darul Kamilin Bakan

2) Pelatihan yang diberikan meningkatkan pemahaman yang lebih comprehesnif bagi para guru dalam penggunaan pendekatan belajar baik secara online atau blended learning dimasa Covid -19. Hal ini ditunjukkan dengan response positif dari para guru yang menyatakan bahwa mereka mendapat pengetahuan baru tentang pendekatan pembelajaran selama Covid-19. Selain itu juga, dari hasil angket yang diberikan; para peserta menyatakan bahwa mereka selain mendapatkan ilmu baru, mereka juga merasa bahwa pelatihan yang diikuti Sangat bermanfaat di masa pandemi ini karena mereka mengetahui sistem pembelajaran dimasa pandemi Covid19 serta banyak pelajaran bisa dipetik terkait pendekatan pembelajaran yang bisa diterapkan selama Covid -19.

Berdasarkan hasil evaluasi pelatihan yang sudah dilaksanakan, tim PKM dan pihak yayasan Arrahman yang menaungi Madarsah Aliyah, Tsanawiyah dan SMK Darul Kamilin berkomitmen untuk mengadakan kerjasama dengan mengadakan pelatihan-pelatihan setiap tahun sesuai dengan kebutuhan serta masukan saran yang diberikan oleh para peserta pelatihan.

\section{Kesimpulan}

Pembelajaran jarak jauh merupakan pendekatan pembelajaran yang harus diterapkan selama keberadaan Covid-19. Berdasarkan respon dari para peserta menunjukkan bahwa kegiatan 
Pengabdian Kepada Masyarakat ini memberikan manfaat yang bagus bagi peserta karena mereka mendapatkan ilmu serta pemahaman yang baru terkait pendekatan pembelajaran selama Covid-19. Paserta juga berharap bahwa program yang sama agar bisa dilakukan diwaktu yang akan datang.

\section{Saran}

Berdasarkan hasil kegiatan pengabdian kepada masyarakat ini, disarankan kepada guru ditingkat Tsanawiyah, Aliyah, SMK Darul Kamilin Bakan untuk mengaplikasikan pendekatan serta media pembelajaran baik secara online ataupun blended learning dimasa pandemic Covid-19 untuk mendukung serta memudahkan proses pembelajaran.

\section{Daftar Pustaka}

Borup, J., Chambers, C.B., \& Stimson, R. (2019). K-12 student perceptions of online teacher and on-site facilitator support in supplemental online courses. Online Learning, 23(4), 253280. doi:10.24059/olj.v23i4.1565

Conklin, S. \& Garrett Dikkers, A. (2021). Instructor social presence and connectedness in a quick shift from face-to-face to online instruction. Online Learning, 25(1), 135-150. https://doi.org/10.24059/olj.v25i1.2482

Dhawan, S. (2021). Online Learning: A Panacea in the Time of COVID-19 Crisis, Journal of Educational Technology Systems 2020, Vol. 49(1) 5-22

Gunawan Setiadine, et al.(2016). The Development of Blended Learning-Based SelfLearning on Classroom Action Research Training Material to Improve Teachers Professionalism. Proceeding The $2^{\text {nd }}$ International Conference On Teacher Training and Education Sebelas Maret University. Volume 2 Number 12016 ISSN : 25002 -4124 .

Hidayatulloh, A., Rijal, K., Pratama, I., \& Malikah, Hr, B. (2021). Pelatihan Pembelajaran Daring Berbasis Zoom untuk Guru MA NW Kabar Kabupaten Lombok Timur. Jurnal Pengabdian UNDIKMA, 2(1), 115-119. doi:https://doi.org/10.33394/jpu.v2i1.3581

Ivanov, D. (2020). Predicting the impacts of epidemic outbreaks on global supply chains: A simulation-based analysis on the coronavirus outbreak (COVID-19/SARS-CoV-2) case. Transportation Research Part E: Logistics and Transportation Review, 136, 101922.

Olasile Babatunde Adedoyin \& Emrah Soykan (2020): Covid-19 Pandemic and Online Learning: The Challenges and Opportunities, Interactive Learning Environments, DOI:10.1080/10494820.2020.1813180.https://doi.org/10.1080/10494820.2020.18131 80

Thorne K. (2003). Blended learning: How to Integrate Online and Traditional Learning. London: Kogan Page Limited.

Uzur, A., \& Senturk, A. (2010). Blending Makes the Diffences Comparison of Blended and Traditional Instruction on Students' Performance and Attitudes in Computer Literacy. Contemporary Educational Technology. Vol. 1 (3), 196-207.

Zainuddin, Z and Keumala, C.M (2018). Blended Learning Method Within Indonesian Higher Education Institutions. Jurnal Pendidikan Humaniora. Volume 6, Number 2, June 2018, pp. 69-77. Available online at http://journal.um.ac.id/index.php/jph. pISSN: 2338-8110/eISSN: 2442-3890. 